\title{
Graduate and Student Attitudes Towards Effective Music Education at the Academy of Music
}

\author{
Daucianskaite Agne, \\ Vytautas Magnus University, Kaunas, Lithuania
}

URL:http://dx.doi.org/10.19044/esj.2019.v15n23p1

\begin{abstract}
This article presents a qualitative study which aimed to explore and describe effective music education through the experience-based opinions of graduates and students of the Academy of Music. The research questions for the empirical research were: How is effective music education described by students/graduates who continuously practice and permanently learn instrumental music? How do they see the role of the teacher as a component in effective music education? The sample consisted of 14 research participants, 7 of whom were graduates and 7 final (4th) year students. In findings, discussion and conclusions these two subgroups are not divided and compared, as qualitative research does not aim to compare, but rather seeks to provide a deep summary (not generalized) description of the phenomenon. Data collection applied semi-structured interviews and the data analysis was performed using thematic analysis. Findings revealed that students related effective music education primarily to a music teacher's personality traits and professional competence. Yet the music teacher's role is seen as broader by graduates/students: a music teacher is important as an equal collaborator in discussions, performances and learning; students need to reflect, they need to experience support and respect for their own decisions in their own music career. In conclusion, it is important to note that effective music education requires from the teacher both a good understanding of music or the ability to master the necessary techniques, and the ability to convey musical traits to the students.
\end{abstract}

Keywords: Academy of music, Career of musician, Effective musical education, Teacher, Qualitative research, Thematic analysis

\section{Introduction}

The success of music education is determined by a wide variety of factors: political, economic, social, cultural changes in the life of society, and the evolution of education science (Gillen, Wright, \& Spink, 2011). In 
effective music education the teaching is an essential condition for fostering learning in instrumental and vocal music. The role of the teacher in music lessons has to be considered in a multidimensional perspective, since it involves different personal and professional aspects in a one-to-one educational relationship. To improve teaching in the music field it is necessary to understand all these elements, the connections between them, and their impact on music teachers' training and professional development. The impact of music teachers' training is also important, since it is a significant dimension of effective music teaching (Concina, 2015).

Researchers from different countries describe effective music education through different research focuses. Georgii-Hemming \& Westvall (2010), concerned with students of music education in Sweden, investigated student teachers' perceptions of their ongoing music teacher education. Their findings led to a discussion of ideological issues with a bearing on democracy, the value of music and the function of music as a curriculum subject. Norwegian researcher Saetre (2018) explored the relationship between teachers' competence and the content of their music lessons. The results indicate that competence is the single most important factor stimulating music making in schools. The qualitative study of USA researcher Gruenhagen (2012) contributed to the conversation on novice music teachers learning in communities and teacher learning in practice. Findings revealed that for effective music education the following aspects are important: structures and frameworks (processes and tools), building community (within classes and with children, and colleagues) and collaboration (support, perspectives, validation, and vision). Nigerian researcher Adeogun (2015) studied the improvement in the preparation of musician-teachers as absolutely imperative to move modern music education as a field in the direction of continued growth. Cheng (2018) from Hong Kong focused on IT implementation in music education and declared that, for example, the laptop ensemble is a platform that has recently been made possible by computer technology enabling individuals to perform music collaboratively. Results of his study showed that participating in a laptop ensemble fostered students' ability to develop both musical and technological skills, which fits with the framework of digital musicianship of essential skills for musicians and music educators in the digital era.

However, in addition to these important aspects in instrumental music education, there are still several aspects that have a significant impact on effective musical education: 1) the relationship between the teacher and the student during the music lesson; 2) the music teacher's competence; 3) the teacher's creativity, organization, communicability during the lesson; 4) class atmosphere; and 5) teaching methods. 
Biasutti \& Concina (2018), Krause \& Davidson (2018) analyzed aspects of effective music education in order to improve student results and individual growth, and to promote positive educational diversity for others. The authors noted that instrumental or professional music teaching provides certain qualities that are different from other academic disciplines. As a result, the music education process is determined by several elements that are important for this instrumental training. First, the main aim of the instrumental vocational training - process is to develop a professional musician. In regard to this idea, students are selected with musical talents, knowledge and musical skills. Second, in informal education one specific music orientated content is taught as well as an intensive specialization orientated one. Third, during an instrumental lesson, the teacher collaborates with the student face to face. This is a special phenomenon when a student is related only with a teacher. Because it is instrumental teaching, at the same time it is necessary to think not only about the diversity of technique and its teaching, but also about the knowledge of music theory, rhythm and hearing.

In this context the following research questions arise: How is effective music education described by students/graduates who continuously practice and permanently learn instrumental music? How do they see the role of the teacher as a component in effective music education?

The aim of this study was to explore and describe effective music education through the experience-based opinions of graduates and students of the Academy of Music.

\section{Methodology}

Approach

In conducting the study, the author of this article maintained the view that effective music education is influenced by these factors: the relationship between a teacher and a student during the music lesson; the music teacher's competence; the teacher's creativity, organization, communicability during the lesson; classroom atmosphere; and teaching methods. The author's qualitative research about effective musical education was viewed from the perspective of professional musicians of various specialties.

Qualitative research is that in which the researcher has been directly involved, and has him/herself examined the research phenomenon in the studied environment (Devetak, Glažar, \& Vogrinc, 2010). Qualitative research in education is focused on the outcomes from the educational researches carried out in different fields, disciplines and qualitative methodological approaches. These investigations have the final purpose of improving educational processes or contexts (Lichtman, 2012). 


\section{Sampling and sample}

The selection of the participants of the study was purposeful. Purposeful sampling is widely used in qualitative research for the identification and selection of information-rich cases related to the phenomenon of interest (Palinkas, Horowitz, Green, Wisdom, Duan, \& Hoagwood, 2015). The way one will engage in purposive sampling signifies that one sees sampling as a series of strategic choices about with whom, where and how one does one's research. This statement implies that research sampling must be tied to researcher objectives. A second implication follows from the first: there is no one best sampling strategy because which is best will depend on the context in which researchers are working and the nature of their research aim (Palys, 2008).

The sample consisted of graduates and students, men and women, aged from 20 to 30 years, who are professional musicians in various spheres. All research participants in the study have already graduated or are studying in their final year at Bachelor's level at the Academy of Music. All of them have been active in music performance for at least 15 years. The sample consisted of 14 research participants, 7 of whom were graduates and 7 were final (4th) year students. In findings, discussion and conclusions these two subgroups are not divided and compared, as qualitative research aims not to compare, but rather seeks to provide a deep summary (not generalized) description about the phenomenon (Jugder, 2016).

\section{Data collection}

Semi-structured interview was chosen as the method for qualitative data collection. Currently, it is widely accepted that interview is the main data and information collection method in qualitative research (Kvale \& Brinkmann, 2009). Many researchers like to use semi-structured interviews because questions can be prepared ahead of time. This allows the interviewer to be prepared and appear competent during the interview. Semi-structured interviews also allow informants the freedom to express their views in their own terms (Blandford, 2013). A semi-structured interview is a meeting in which the interviewer does not strictly follow a formalized list of questions. They will ask more open-ended questions, allowing for a discussion with the interviewee rather than a straightforward question and answer format (Kvale \& Brinkmann, 2009). That is why the author of this study has chosen this method for qualitative data collection.

\section{Research tool}

Questions provided to research participants at a time of semistructured interviews were the tool for qualitative data collection. The tool 
consisted of the following five main questions to some of which were added further questions (in total three questions):

1. Main question: "Tell me about your musical path?” Further question: "Why did you choose it?"

2. Main question: "How many teachers did you meet on your musical path who influenced you on your further musical path?" Further question: "Tell me about the teachers who were authorities to you and you could say that they were effective?"

3. Main question: "Describe your experience with the teacher who has made an impact on your musical development?"

4. Main question: "Tell the most memorable event related to your effective teacher?" Further question: "How did that teacher inspire you?"

5. Main question: "Is the teacher's opinion important to your musical career as an artist/soloist/musician now?"

\section{Data analysis}

Thematic analysis was chosen as the method for data analysis in this study.

Thematic analysis (TA) is a widely-used qualitative data analysis method. It is one of a cluster of methods that focus on identifying patterned meaning across a dataset.

The purpose of TA is to identify patterns of meaning across a dataset that provide an answer to the research question being addressed (Maguire \& Delahunt, 2017).

TA is used in qualitative research and focuses on examining themes within data. Coding is the primary process for developing themes within the raw data by recognizing important moments in the data and encoding them prior to interpretation (Jugder, 2016).

Themes are presented through in vivo interview statements.

\section{Findings}

Theme: The multilayered beginning of the professional musician's path: Everything happened really completely unplanned, I had been thinking about music, because I was the only child who didn't go to music school. (RI)

The musical path of all the musicians who participated in the research began very differently. For some musicians this was an unexpected choice:

Well, my musical path started very unexpectedly. My mother found an advertisement that children are accepted to play instruments at a music school. (R3)

Other participants did not even think about a musician's career at first: 
Then I thought and told myself that I would never go to the music school and I never related my future with music because it is hard to live on. But after a while, everything turned around. (R2)

Yet others thought that music has chosen them itself:

I think that music has chosen me itself. Since early childhood, music has been beside me because I had a childish dream to be a singer and it came true. (R5)

There was also a big influence on the musical path chosen by the parents:

I have chosen my musical path. My parents put a lot of attempts in order to put me in this direction. They helped me a lot, encouraged me and supported me as well. (R6)

For some musicians it was a coincidence:

Everything started by chance. Accidentally I came to music school: some teachers from music school were looking for gifted students who could and would like to enter music school. (R4)

Theme: Teacher's personality influence on a professional music career: $M y$ first music teacher spoke about the musician's path very attractively and with a great love. Being a musician to me is a wonderful gift. (R11)

Research participants spoke differently about their teachers' personalities and their influence on them. Not only the teachers of specialty but also the teachers of theoretical subjects, contributed a lot to a general music cognition of musicians:

Being a musician, I have met numerous brilliant music specialists. The first specialty teacher has not only been my specialty teacher, she has been my life teacher as well. Studying in the music academy, I had a wonderful professor who motivated me a lot. (R7)

Musicians have met a lot of specialty teachers who have helped them during different music stages:

I had three specialty teachers of singing and they contributed a lot to my musical path. In all I got singing lessons as well as life ones, interesting stories about music. (R10)

Some participants gained music knowledge from their teachers as well as perceptions on their future career as a teacher and as a musician:

I have met wonderful teachers in my path. Certainly, they were the teachers of my specialty, but most of them "crashed" into my memory. These people not only gave me knowledge, they showed and explored to me a good example as well. (R8)

Some participants said that teachers they met did not influence their music career:

Sincerely speaking none of teachers where I was studying made anything special to me. (R9) 
Theme: Being more than an ordinary music teacher: That teacher has really taught me a lot. <...> he has taught me how to work, how long I have to play in order to reach good results and how to study, how to understand right. (R14)

Research participants have distinguished different qualities of their teachers, but the main ones were the following: love of music, lessons in life, education of inner personal qualities. For some participants, the teacher has provided not only technical musical features, but also determination, how to survive as a true artist:

When I was younger, I always thought I was playing well, but after joining higher level music studies I realized it wasn't like I thought. And finally, the teacher himself told me that it was not as good as I thought. Frankly, I did the best I could, I felt a very big encouragement from my family members. And the teacher himself did his best. (R13)

By the way, my main professor has put me on the right path. And I can say that he formed me as a musician. (R12)

Research participants thought that when they were "immature" they could not gain all the knowledge that the teacher gave to them:

Perhaps I gained the greatest influence on my musical development from the last teacher who gave me the most for my vocal knowledge. (R11) Other participants claimed that they were influenced not only by their professors, but by their friends who were beside them:

One friend had a big influence on me. Being beside him, I had the opportunity to observe the whole creative process. And it is not a technique, it is a general understanding, perception of what music is. (R12)

Theme: Being in togetherness with the teacher by experiencing teaching through example(s): The most memorable thing was singing with the teacher while the symphony orchestra was playing. (R10)

Effective music education, according to participants, requires not only pedagogic precision and strict work; they accentuated that informal surrounding is also very important. Some participants memorize events related to the teachers who integrated formal and informal education or relationship(s):

There is an event which happened with the professor. The lecture was going on, I performed the music piece and he said to me: "You know what, you are very similar to a basketball player S. Jasikevicius". At first I did not understand him. So, later he said: "You are a fighter as he is". His words touched me. (R9) 
Some research participants experienced great satisfaction when they attended their professors' concerts:

The most memorable event was my teacher's anniversary concerts and the preparation for them, where I had the opportunity to sing for the first time at such level concerts, sing with the orchestra and perform for a very special audience. (R14)

For other participants, the most memorable events with the teachers were traveling and competitions:

I cannot say that there is only one memorable event. Since childhood, traveling together remained in my memory. $(R 7)$

Participants believed that the best events were those where they had the opportunity to become acquainted with a lot of professional musicians:

I am very glad that I had the opportunity to meet my last teacher of the Academy. One of many such events was that I got to know him and I knew a lot of bright specialists with whom I had to work and cooperate. (R6)

Theme: Importance of teacher's opinion: It is very important because if you take a new piece of music that you have never heard and seen before, then who will give you advice if it is not the teacher? (R5)

During the research participants pointed out that music teacher's opinion is important at every stage of learning and career (not least when starting it). Thus, some participants affirm that the teacher's opinion is very important especially while studying:

The Professor's opinion for my music career was really of great importance. Especially during my studying years I was listening to it. (R8)

Other participants have claimed that for the musician student and the graduate it is very important to have both your own opinion and to listen to a professor's opinion, while at the same time trying to find out your own path:

Well, I would say that you have to listen the professor with "one ear". If the things the professor says to you are acceptable, then you have to accept them. (R4)

But research participants also think that it is necessary to get the most out of the teacher, and if the good relationship is maintained after the studies, it is wonderful:

You have to listen to your teacher when you really have no idea what to do and when to start. (R9)

Other participants think that it is meaningful to collaborate with your former teacher continuously or permanently: 
My teacher's opinion on my music career is very important. I know people who finished studies 10 years ago, but they still have consultations with their teachers. (R1)

\section{Discussion}

In this article, the author revealed and presented a variety of participants' opinions through the thematic analysis.

The participants in the research paid substantial attention to the teacher's personality and professional competences which show his/her expertise in the particular music field. All the participants unanimously mentioned that the main trait of an effective music teacher is his/her devotion to music teaching. In other words, the love for his/her work and the ability to convey that love in this case for the world of music - to students. In addition, the participants put a huge emphasis on the teacher's proficiency in the particular music field. Thus the research revealed that the competence of pedagogues encourages effective learning. This conclusion was also confirmed in various research studies by Gruenhagen (2012), Adeogun (2015), Krause \& Davidson (2017). To some of the participants, pedagogues were not only their music teachers but also people who taught them valuable life lessons. These pedagogues were able to understand, support, and help the participants in overcoming difficult situations. Moreover, the participants were taught about trust, love for music and professionalism in the world of music. Some researchers - Gillen, Wright, \& Spink (2011), Reyes, Brackett, Rivers, White, \& Salovey (2012) accentuate the importance of the teacher's personality traits in relation to effective teaching.

Research findings showed that the positive and supportive connection between the teacher and the student encourages the further and continuous effective music career of the musician. These findings are in line with the research findings of Concina (2015) and Cheng (2019). Then, when the relationship between a teacher and the student is based on equal partnership, mutual understanding, discovery of positive qualities, respect and love for a person, all of these elements encourage an effective music education which puts the student on the creative path in his/her music career (Biasutti \& Concina, 2017).

\section{Conclusion}

Effective music education depends not on the student's desire to be a professional musician, but primarily on the professionalism, competence and traits of the music teacher. Thus, effective music education requires from the teacher not only a good understanding of music or the ability to master the necessary techniques, but also the ability to convey musical traits to students. 
Students need to feel the support of the music teacher, his/her understanding and his/her leading towards the knowledge of music of the students. However, students need to work on the development of personal understanding about the music, to develop their personal interpretation of the music, and therefore they need a dialogue with the music teacher. Students need to have an opportunity to reflect through discussion with the music teacher and be accepted and respected (nevertheless they could be criticized) for their original vision and courage to express it orally in discussion and through performing the music.

\section{References:}

1. Adeogun, A. O (2015). Reconceptualizing the Music Teacher Education Curriculum for the Colleges of Education in Nigeria. SAGE Open, 5(2). Retrieved from https://journals.sagepub.com/doi/10.1177/2158244015585608

2. Biasutti, M., \& Concina, E. (2017). The effective music teacher: The influence of personal, social, and cognitive dimensions on music teacherself-efficacy. Musicae Scientiae, 22(2): 264-279.

3. Blandford, A. (2013). Semi-structured qualitative studies. In: Soegaard, Mads and Dam, Rikke Friis (Eds.). The Encyclopedia of Human-Computer Interaction. (2nd Ed.). Aarhus, Denmark: The Interaction Design Foundation. Retrieved from http://www.interaction- design.org/encyclopedia/semistructured_qualitative_studies.html

4. Cheng, L. (2018). Musical competency development in a laptop ensemble. Research Studies in Music Education, 41(1): 117-131.

5. Concina, E. (2015). Music Education and Effective Teaching: Perspectives from a Critical Review. Literacy Information and Computer Education Journal, 6(2): 1892-1895.

6. Devetak, I., Vogrinc, J., \& Glažar, S. A. (2010). The Role of Qualitative Research in Science Education. Eurasia Journal of Mathematics, Science and Technology Education, 6(1): 77-84.

7. Gillen, A., Wright A., \& Spink L. (2011). Student perceptions of a positive climate for learning: a case study. Educational Psychology in Practice, 27(1): 65-82.

8. Georgii-Hemming, E., \& Westvall, M. (2010). Teaching music in our time: student music teachers' reflections on music education, teacher education and becoming a teacher. Review of Music Education Research, 12(4): 353-367.

9. Gruenhagen, L. M. (2012). Learning in practice: A first-year early childhood music teacher navigates the complexities of teaching. Research Studies in Music Education, 34(1): 29-44. 
10. Judger, N. (2016). The thematic analysis of interview data: an approach used to examine the influence of the market on curricular provision in Mongolian higher education institutions. Semantic Scholar, Hillary Place Papers. (3rd Ed.). UK: Leeds University. Retrieved from https://pdfs.semanticscholar.org/2e0a/746b717fa49b6f4a48a462ee47 e602204de9.pdf?_ga=2.1637305.907258403.15632142471174538392.1563214247

11. Krause, A. E., \& Davidson, J. W. (2018). Effective Educational Strategies to Promote Life-Long Musical Investment: Perceptions of Educators. Frontiers in Psychology. Retrieved from https://www.frontiersin.org/articles/10.3389/fpsyg.2018.01977/full

12. Kvale, S., \& Brinkmann, S. (2009). InterViews: Learning the craft of qualitative research interviewing. Los Angeles, CA: Sage Publications.

13. Lichtman, M. (2012). Qualitative Research in Education: A User's Guide. London: SAGE.

14. Maguire, M., \& Delahunt, B. (2017). Doing a thematic analysis: a practical, step-by-step guide for learning and teaching scholars. The All Ireland Journal of Teaching and Learning in Higher Education, 9(3): 3351-33514.

15. Palinkas, L. A., Horwitz, S. M., Green, C. A., Wisdom, J. P., Duan, N., \& Hoagwood, K. (2015). Purposeful Sampling for Qualitative Data Collection and Analysis in Mixed Method Implementation Research. Administration and Policy in Mental Health, 42(5): 533-544.

16. Palys, T. (2008). Purposive sampling. In L. M. Given (Ed.) The Sage Encyclopedia of Qualitative Research Methods, 2: 697-698. Los Angeles: Sage.

17. Reyes, M. R., Brackett, M. A., Rivers, S. E., White, M., \& Salovey P. (2012). Classroom Emotional Climate, Student Engagement, and Academic Achievement. Journal of Educational Psychology, 104(3): 700-712.

18. Saetre, J. H. (2018). Why school music teachers teach the way they do: a search for statistical regularities. Music Education Research, 20(5): 546-559. 